\title{
КЛЮЧОВІ ФУНКЦІОНАЛЬНІ ЗМІНИ У КЛІТИНАХ БРИЖОВИХ ЛІМФАТИЧНИХ ВУЗЛІВ НАЩАДКІВ ЩУРІВ 3 ЕКСПЕРИМЕНТАЛЬНИМ ГЕСТАЦІЙНИМ ДІАБЕТОМ
}

Ключові функціональні зміни у клітинах брижових лімфатичних вузлів нащадків щурів 3 експериментальним гестаційним діабетом Т. М. Прозорова, К. С. Крупєй, О. М. Камишний Запорізький державний медичний університет

Резюме. Гестаційний діабет (ГД) є важливим порушенням обміну речовин, що може впливати на морфоггенез органів імунної системи.

Мета дослідження - з'ясувати особливості змін фрункціонального стану клітин брижових лімфатичних вузлів у нащадків щурів з експериментальним гестаційним діабетом (ЕГД).

Матеріали і методи. Дослідження проведено на 80 нащадках щурів лінії Wistar з ЕГД віком 1 i 6 місяців. Для індукції ЕГД вводили внутрішньочеревно стрептозотоцин (SIGMA Chemical, США) у дозі 45 мг/ка. Для ідентифрікації TLR2, TLR4, NOD2, RIGI, T-bet, NIrp3, RORyt i Foxp3 у гістологічних зрізах лімфратичних вузлів застосовували імунофлюоресцентний метод. Для дослідження експресії мPHК генів Aire, Deaf1, Foxp3, IL10, Ctla4, Cxcr4, Ccr7, Madcam1, S1pr1 використовували метод полімеразної ланцюгової реакції зі зворотною транскрипцією в режимі реального часу.

Результати. Встановлено комплекс ключових патофрізіологічних і фуункціональних змін у клітинах брижових лімфатичних вузлів (БЛВ) у нащадків щурів з ЕГД: зміни експресії регуляторів рециркуляції і хоумінгу лімфроцитів; порушення фоормування периферичної імунологічної толерантності; активація патернрозпізнавальних рецепторів уродженої імунної системи на лімфоцитах БЛВ; зміни розподілу ефекторних Т-клітин в БЛВ.

Висновки. Пренатальна гіперглікемія призводить до посилення прозапальної сигналізації та активації компонентів уродженої імунної системи більш виразно на 1 місяці життя.

Ключові слова: експериментальний гестаційний діабет; брижові лімфатичні вузли; уроджений імунітет.

\section{ВСТУП}

Гестаційний діабет (ГД) є важливим порушенням обміну речовин, що виявляється у 2-6 \% всіх вагітностей та значно підвищує ризики матері та
Key functional changes in mesenteric lymphatic node cells in the posterity of rats with experimental gestational diabetes

T. M. Prozorova, K. S. Krupey, O. M. Kamyshnyi Zaporizhzhia State Medical University

e-mail: prozorova_t@i.ua

Summary. Gestational diabetes (GD) is an important metabolic disorder that can affect the morphogenesis of the immune system.

The aim of the study - to find out the peculiarities of mesenteric lymph nodes cells functional state in the posterity of rats with experimental gestational diabetes (EGD).

Materials and Methods. Studies were performed on 80 posterity of Wistar rats with EGD at 1 and 6 months of age. For the induction of EGD streptozotocin (SIGMA Chemical, USA) was administered intraperitoneally at a dose of $45 \mathrm{mg} / \mathrm{kg}$. For identification of TLR2, TLR4, NOD2, RIGI, T-bet, NIrp3, RORyt and Foxp3 in histological sections of lymph nodes immunofluorescence method was used. To study the mRNA expression of Aire, Deaf1, Foxp3, IL10, Ctla4, Cxcr4, Ccr7, Madcam1, S1pr1 genes, a real-time reverse transcription polymerase chain reaction method was used.

Results. The complex of key pathophysiological and functional changes in cells of mesenteric lymph nodes $(M L N)$ in the posterity of rats with EGD was established: changes in the expression of lymphocyte recycling regulators and homemaking; impaired formation of peripheral immunological tolerance; activation of patterns of recognition receptors of the innate immune system on MLN Iymphocytes; changes in the distribution of effector T cells in MLN.

Conclusions. Prenatal hyperglycemia leads to increased proinflammatory signaling and activation of innate immune system components more clearly at 1 month of life.

Key words: experimental gestational diabetes; mesenteric lymph nodes; innate immunity.

плода [1]. При цьому вплив ГД простягається далеко за межі перинатального періоду і віддалено впливає на розвиток ожиріння і діабету 2 типу. Вагітність у нормі викликає зміни імунного статусу в 
напрямку імуносупресії, проте у жінок із ГД спостерігається збільшення маркерів активації Т-лімфроцитів, самих Т-клітин та дефіцит цитотоксичного Т-лімсроцитасоційованого протеїну 4 (CTLA-4). Тобто інтранатальна гіперглікемія, що розвивається за умови ГД, може впливати на морфрогенез органів імунної системи $[2,3]$.

Формування імунологічної толерантності до власних антигенів (Аг) є важливим механізмом, що попереджує розвиток аутоімуних захворювань (AI3) [4]. В останні роки було розроблено екстратимічну експресію цілого ряду перифреричних тканинноспециорічних антигенів (peripheral tissuespecific antigens, PTSAs), у тому числі таких панкреатичних Аг, як інсулін та проінсулін, регулятором ектопічної транскрипції яких $€$ аутоімунний регулятор (Aire) [5]. Численні екстратимічні Aireекспресуючі клітини (extrathymic Aire-expressing cells, eTACs) локалізуються у лімсратичних вузлах (ЛВ) та є одним із критичних фракторів формування периферичної імунної толерантності (ПІТ) [6]. Клітини строми ЛВ експресують PTSAs, однак регулюється їх експресія не лише еTACs, а й транскрипційним регулятором Deaf1 (deformed autoregulatory factor 1) [7]. У свою чергу, Aire та Deaf1 $€$ регуляторами диференціювання ще одного учасника негативного контролю розвитку Al3 індуцибельних Т-регуляторних клітин (iTreg), експресуючих транскрипційний фрактор Foxp3 [8]. Дія iTreg реалізується через продукцію супресорних цитокінів - IL10, IL13, IL35, TGF $\beta$ та залежить від експресії CTLA-4 [9]. Так, стромальні Deaf1експресуючі клітини брижових лімфратичних вузлів (БЛВ) продукують ретиноєву кислоту, яка сприяє розвитку Foxp3+-регуляторних Т-клітин [10], a Yang S. Et al. показали здатність Aire генерувати у перинатальний період особливу популяцію Foxp3+Tregклітин, яка стійко зберігається у дорослих мишей також [11]. Місце експонування Аг має вирішальне значення для підтипу регуляторних Т-клітин і механізму індукції толерантності [12].

Метою дослідження було з'ясувати особливості змін фрункціонального стану клітин брижових лімфатичних вузлів у нащадків щурів з експериментальним гестаційним діабетом (ЕГД) за допомогою імунофлюоресцентних і молекулярно-генетичних методів.

\section{МАТЕРІАЛИ I МЕТОДИ}

Дослідження проведено на 80 нащадках щурів лінії Wistar віком 1 і 6 місяців. Тварини перебували в умовах природного освітлення при вільному доступі до води та їжі на віварії Запорізького державного медичного університету.

Для індукції експериментального гестаційного діабету (ЕГД) стрептозотоцин (SIGMA Chemical,
США) вводили щурам внутрішньочеревно у дозі 45 мг/кг, розчиненому у 0,5 мл 0,1 М цитратному буфрері $(\mathrm{pH}=4,5)$ на 14-15 добу датованої вагітності щура, що відповідає останньому триместру вагітності [13]. На 2-3 добу після введення стрептозотоцину в усіх самок після 10-годинного голодування визначали вміст глюкози у крові 3 хвостової вени глюкозооксидазним методом. В експеримент відбирали тварин із рівнем глікемії більше 8 ммоль/л.

Експериментальних тварин поділили на 4 групи: перша група - нащадки контрольних щурів лінії Wistar віком 1 місяць ( $\mathrm{n}=20)$; друга група - нащадки контрольних тварин лінії Wistar віком 6 місяців $(n=20) ;$ третя група - нащадки щурів лінії Wistar 3 ЕГД віком 1 місяць (n=20); четверта група - нащадки щурів лінії Wistari з ЕГД віком 6 місяців $(n=20)$.

Для ідентиорікації TLR2 і TLR4 у гістологічних зрізах БЛВ застосовували прямий імунофлюоресцентний метод із використанням моноклональних антитіл, кон'югованих з флюоресцеїну ізотіоционатом (FITC). Для ідентифікації NOD2, RIGI, T-bet, NIrp3, RORyt i Foxp3 у гістологічних зрізах ПЛВ застосовували непрямий імунофрлюоресцентний метод із застосуванням відповідних поліклональних антитіл. Структуру популяції імунопозитивних клітин вивчали на основі аналізу серійних гістологічних зрізів і даних їх морфометричних та денситометричних характеристик, за допомогою комп'ютерної програми Image J (NIH, CША). Зображення отримували на мікроскопі PrimoStar (ZEISS, Німеччина) в ультрасріолетовому спектрі збудження 390 нм (для FITC) за допомогою високочутливої камери AxioCam 5c (ZEISS, Німеччина) і пакета програм для отримання, архівування та підготуваання зображень до публікації AxioVision 4.7.2 (ZEISS, Німеччина). Вивчали імунопозитивні клітини, розташовані у паракортикальній зоні й мозкових тяжах БЛВ.

Для дослідження експресії MPHK генів Aire, Deaf1, Foxp3, IL10, Ctla4, Cxcr4, Ccr7, Madcam1, S1pr1 використовували метод полімеразної ланцюгової реакції зі зворотною транскрипцією в режимі реального часу (ЗТ-ПЛР-РЧ) і застосуванням ампліфрікатора CFX96 ${ }^{\mathrm{TM}}$ Real-Time PCR Detection Systems з програмним забезпеченням CFX Manager тм(BioRad, США). Використовували архівний гістологічний матеріал (парафрінові блоки) віком 3 роки. Тотальну РНК отримували 3 гістологічних зрізів завтовшки 15 мкм, для цього проводили їх попередню депарафрінізацію у ксилолі та регідратацію в низхідних концентраціях етанолу (100; 96; 70 \%). Підготовлені зразки гомогенізували, поміщали в пробірки «Axygen» (США), проводили додаткову депарафрінізацію і повторну регідратацію тканин, згідно з протоколом дослідження. Виділення тотальної РНК виконували із використанням набору «Trizol RNA Prep 100» («И3О- 
ГЕН», РФ), для синтезу кДНК проводили реакцію зворотної транскрипції із використанням набору ОТ-1 фрірми «Синтол» (РФ). Молекулярно-генетичні дослідження рівня експресії мРНК генів здійснювали за допомогою ампліфікатора CFX96 ${ }^{\mathrm{TM}}$ Real-Time PCR Detection Systems («Bio-Rad Laboratories, Inc.», США) і набора реактивів Maxima SYBR Green/ROX qPCR MasterMix (2X) (ThermoScientific, США). Специсрічні пари праймерів для аналізу досліджуваних і рефреренсного генів були підібрані за допомогою програмного забезпечення PrimerBlast (www.ncbi. nlm.nih.gov/tools/primer-blast) та виготовлені фрірмами Metabion (Німеччина) i ThermoScientific (США). В якості референс-гена для визначення відносного значення зміни рівня експресії досліджуваних генів було використано ген гліцеральдегід-3-сросфрат дегідрогенази (GAPDH). Відносну нормалізовану кількість кДНК таргетних генів визначали за методом Ct. Статистичний аналіз даних ПЛР проводили за допомогою програмного забезпечення CFX ManagerTM (Bio-Rad, США). В експеримент були включені негативні контролі: без додавання кДНК матриці в реакцію ПЛР, без додавання мРНК матриці у синтезі кДНК, без додавання фрермента в синтезі қДНК. Усі реакції амплісрікації виконували на індивідуальних зразках у трьох повторах.

Одержані експериментальні дані обробляли на персональному комп'ютері за допомогою ліцензійного статистичного пакета «Statistica for Windows 6.0» (StatSoftInc., №AXXR712D833214FAN5). Для усіх показників розраховували значення середньої арифметичної вибірки (М), її дисперсії і помилки середньої (m). При порівнянні даних використовували параметричний t-критерій Стьюдента, після чого визначали можливість різниці вибірок (р) і довірчий інтервал середньої. При перевірці статистичних гіпотез нульову гіпотезу відкидали при р<0,05.

\section{РЕЗУЛЬТАТИ ТА ОБГОВОРЕННЯ}

У результаті проведеного дослідження встановлено, що у нащадків щурів з ЕГД спостерігається значне зниження вмісту мРНК аутоімунного регулятора (у 8,1 раза $(p<0,05)$ у 1-місячних та у 2,3 раза $(p<0,05)$ у 6-місячних тварин порівняно 3 контролем. Вміст мРНК транскрипційного регулятора Deaf1 у 1-місячних нащадків достовірно не змінився, а у 6-місячних спостерігалося його зменшення у 9,2 раза $(p<0,05)$. Що стосується вмісту мРНК транскрипційного фрактора Foxp3, то у 1-місячних щурів цієї групи виявлено його зменшення у 50,0 разів ( $p<0,05)$, а у 6-місячних - у 2,5 раза $(p<0,05)$ порівняно з контролем.

Наступним етапом стало визначення кількісного рівня транскриптів генів-регуляторів рециркуляції і хоумінгу лімфоцитів Madcam1, S1pr1, Cxcr4 і CCR7, а також характеру експресії мPHK NLRP3інфрламасоми і розподілу NLRP3+-клітин в БЛВ у нащадків щурів з ЕГД. Ми з'ясували, що у нащадків щурів з ЕГД спостерігається значне збільшення вмісту мРНК гена Ccr7 - у 26,8 раза у 1-місячних та у 21,0 разів у 6-місячних. Що стосується вмісту мРНК рецептора Cxcr4, то в обох вікових групах він достовірно не змінився. Відносна нормалізована кількість мРНК адресину MAdCAM-1 у 1-місячних зросла у 2,4 раза, а у 6-місячних - у 2,3 раза. При дослідженні експресії гена S1pr1 були отримані такі результати: у першій віковій групі вміст мРНК S1PR1 збільшився у 3,6 раза, у 6-місячних тварин цей показник зріс у 5,0 разів.

Відомо, що брижові лімфратичні вузли (БЛВ) $€$ головним місцем індукції периферичної імунологічної толерантності до різноманітних антигенів, у тому числі й панкреатичних [14]. Крім того, БЛВ $€$ головним «перехідним» пунктом для пулу рециркулюючих лімфроцитів кишковоасоційованої лімфооїної тканини. Головними регуляторами «роумінгу» лімфроцитів у БЛВ є адресин MAdCAM-1, хемокінові рецептори CXCR4 і CCR7 [15]. У свою чергу, вихід лімфоццитів із БЛВ регулюється сорінгозин-1фросфрат (S1P) рецепторами (S1PR1-S1PR5) [16], серед яких лімфоцитами найбільш активно експресується 1 тип - S1PR1 [17]. Після активації імунних клітин у БлВ експресія S1PR1 на їх мембрані зростає, що дозволяє лімфоцитам відповідати на градієнт S1P і залишати лімфатичні вузли [18].

CCR7-опосередковані сигнали впливають на Т-клітинний гомеостаз у лімфатичних вузлах на різних рівнях, а також на активацію і поляризацію різних субпопуляцій Т-хелперів [19]. Так, CCR7 відіграє важливу роль у фрункціонуванні Т-регуляторних клітин, виконуючи при цьому подвійну роль: для індукованих Treg експресія CCR7 необхідна для їх ефективного праймування в ЛВ [20]; у той час як «ефекторні» Tregs, вочевидь, використовують CCR7 для виходу з тканин і тому CCR7 обмежує їх надмірне накопичення у периорерійних тканинах [21].

Виявлене нами збільшення рівня мРНК ще одного з регуляторів "хоумінгу" лімфоцитів - MAdCAM-1 в БЛВ, яке ми виявили, підтвердили й інші дослідження, в яких показано, що РНК транскрипти MAdCAM-1 добре експресуються в ендотелії як лімфоїдної, так і нелімфоїдних тканин, зокрема у тонкій і товстій кишках, мезентеріальних і панкреатичних лімфовузлах, селезінці [22]. Даних про експресію MAdCAM-1 у БЛВ у нащадків з ЕГД немає. Відомо лише, що адгезія лімфоцитів, що регулюється системою $\alpha 4 \beta 7$ інтегрин/MAdCAM-1, вкрай важлива для міграції В-клітин у панкреатичні лімфатичні вузли (ПЛВ) у діабетичних мишей без ожиріння (NOD). Так, В-лімфоцити з ПлВ 3-4-тижневих NOD-мишей характеризуються високим рівнем експресії інтегрину $\alpha 4$, LFA-1 і проміжним рівнем інтегрину $\beta 7$. В дослідженні in vivo було показано, що В-клітини мігру- 
вали 3 кровотоку в ПлВ більш еорективно, ніж в периореричні ЛВ. Крім того, антитіла до МАdCAM-1 і інтегрину а4ß7 пригнічували міграцію більш ніж 90 \% В-лімфоцитів в ПЛВ [23].

Розвиток ЕГД супроводжувався транскрипційною індукцією гена NIrp3 у БЛВ у нащадків, рівень мРНК якого зріс у 5,0 разів $(p<0,05)$ у 1-місячних і в 3,0 рази $(p<0,05)$ у 6-місячних тварин. У нащадків щурів 3 ЕГД також зростає щільність популяції NLRP3+-лімфоцитів у БЛВ, більш виразно на ранніх термінах спостереження.

Аналіз розподілу рецепторів уродженого імунітету показав, що пренатальна гіперглікемія призводить до зростання кількості TLR2 ${ }^{+}-$, TLR4 $^{+}$-, NOD2 ${ }^{+}$- і $\mathrm{RIGI}^{+}$-лімфроцитів у БЛВ в нащадків, більш виразно на 1 місяць життя, змінює щільність ПРР на імунних
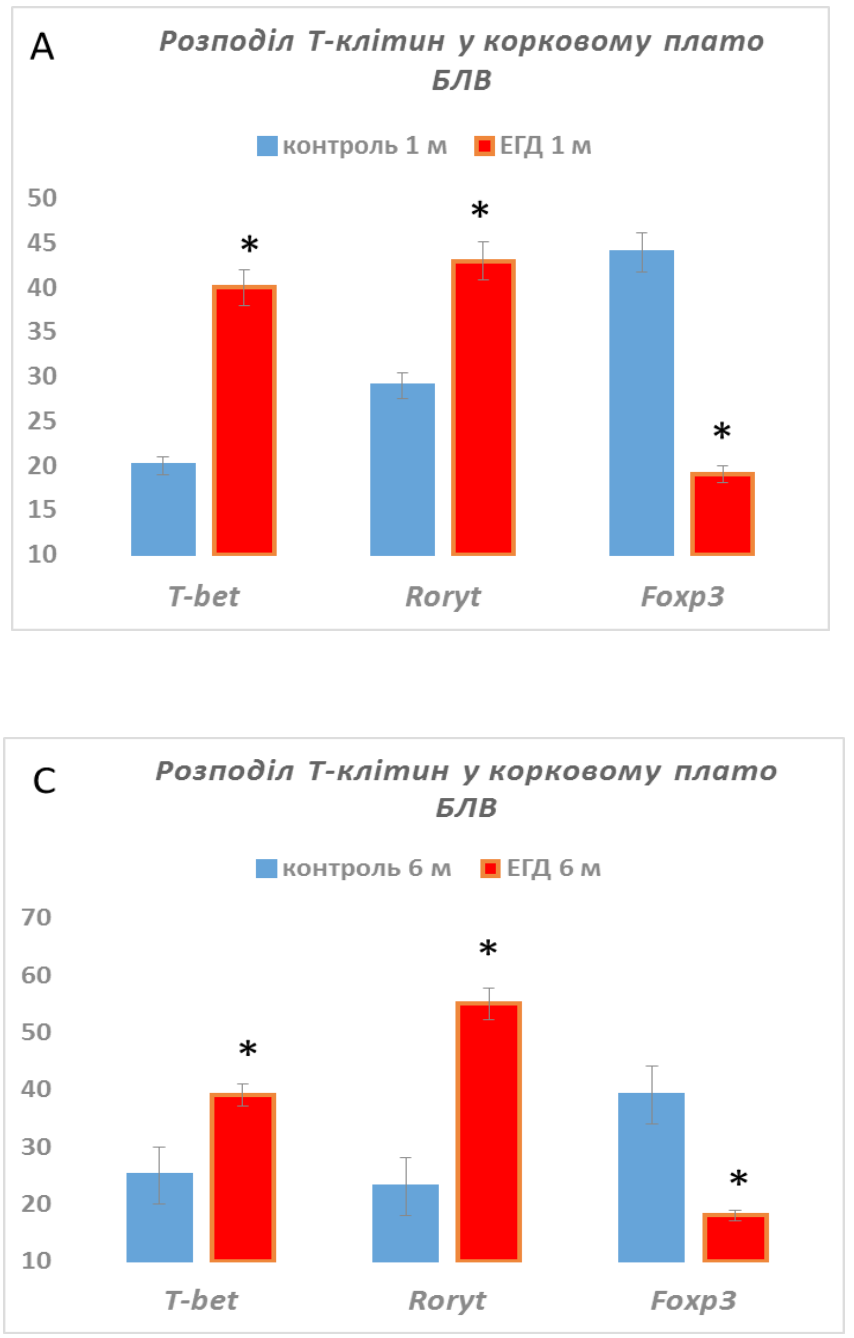

клітинах. В умовах формування оральної толерантності до інсуліну в 1-місячних нащадків у кірковому плато БЛВ зменшується чисельність TLR2 ${ }^{+}$- i TLR4 ${ }^{+}-$ лімфроцитів, у мозкових тяжах - TLR2+- i RIG-I+клітин. Динаміка щодо зменшення кількості клітин, імунопозитивних до ПРР у кірковому плато БЛВ зберігається до 6-місячного віку, супроводжується переважним зменшенням щільності мембранних і концентрації цитоплазматичних РВІ в обох вікових групах, насамперед у лімсробластів.

Ми показали, що пренатальна гіперглікемія призводить до зростання кількості T-bet ${ }^{+}$- i RORyt ${ }^{+}-$ лімфоцитів у БЛВ в нащадків, більш виразно на 1 місяць життя, а також призводить до зменшення кількості Fохр3+-лімфоцитів та змінює щільність ПРР на імунних клітинах (рис.).

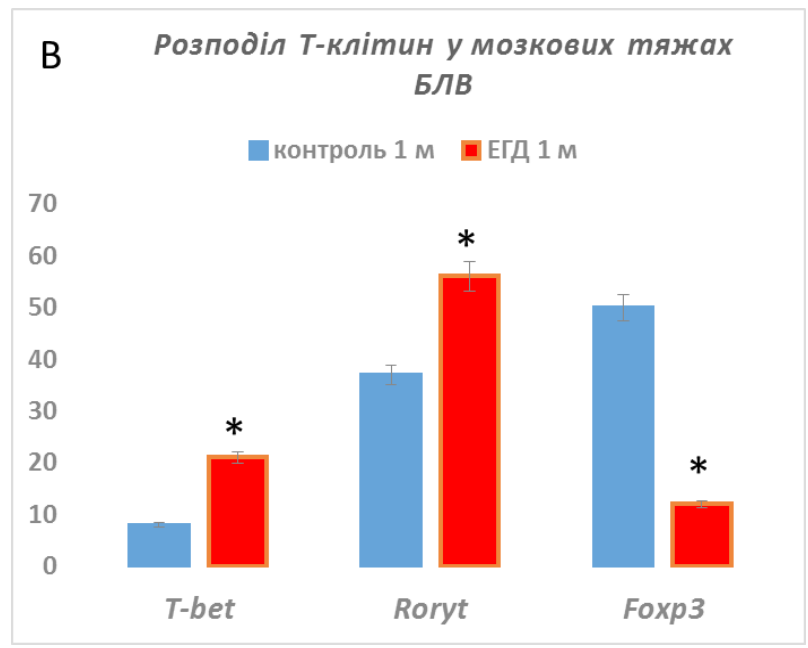

D

Розподіл Т-клітин у мозкових тяжах Блв

понтроль 6 м пегд 6 м

60

50
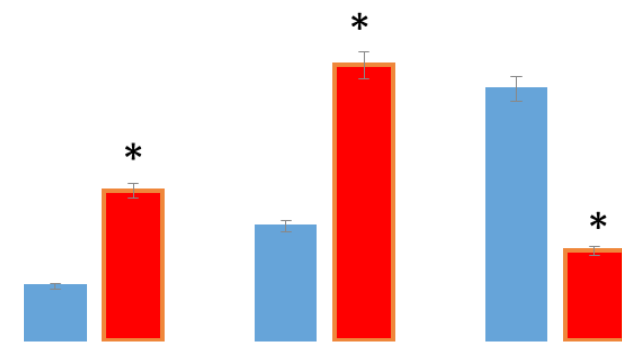

T-bet

Roryt

Foxp 3

Рис. Сумарна щільність (на 1мм²) імунопозитивних лімфоцитів у кірковому плато (A, C) та мозкових тяжах (B, D) брижових лімфатичних вузлах у нащадків щурів лінії Wistar.

Примітка. *- $p<0,05$

\section{ВИСНОВКИ}

Ми виявили цілий комплекс ключових патосрізіологічних і фрункціональних змін у клітинах брижо- вих лімфатичних вузлів (БЛВ) у нащадків щурів 3 експериментальним гестаційним діабетом: зміни експресії регуляторів рециркуляції і хоумінгу лім- 
фоцитів; порушення орормування периферичної імунологічної толерантності; активація патернрозпізнавальних рецепторів уродженої імунної системи на лімфоцитах БЛВ; зміни розподілу ефектор-

\section{СПИСОК ЛІТЕРАТУРИ}

1. Eades C. E. Prevalence of gestational diabetes mellitus in Europe: A meta-analysis / C. E. Eades, D. M. Cameron, J. M. Evans // Diabetes Res. Clin. Pract. -2017. - Vol. 129. - P. 173-181.

2. Innate immune responses to toll-like receptor stimulation are altered during the course of pregnancy / S. M. Ziegler, C. N. Feldmann, S. H. Hagen [et al.] // J. Reprod. Immunol. - 2018. - Vol. 128. - P. 30-37.

3. Prozorova T. M. Effect of experimental gestational diabetes and administration of glibenclamide on mRNA level of NLRP3-inflammasome and distribution of $\mathrm{NLRP3}^{+}$-cells in mesenteric lymph nodes in offspring / T. M. Prozorova, V. A. Kamyshna, A. M. Kamyshny // Pathologia. - 2017. Vol. 14 (2). - P. 149-155.

4. Analysis of cytoarchitectonics of TLR2+ and TLR4+ lymphocytes and transcriptional activity of the genes $\mathrm{Gp} 2$, Spi-B, Nf-kB1, c-REL, TNF $\alpha$ and TNFr IN GALT of rats in experimental diabetes mellitus and after pentoxifylline administration / A. S. Degen, G. D. Koval, I. E. Sukhomlinova [et al.] // Medical Immunology (Russia). - 2019. - Vol. 21, No. 5. - P. 821-834.

5. Metzger T. Control of central and peripheral tolerance by Aire / T. Metzger, M. Anderson // Immunol. Rev. 2011. - Vol. 241, No. 1. - P. 89-103.

6. Peribiliary glands as a niche of extrapancreatic precursors yielding insulin-producing cells in experimental and human diabetes / G. Carpino, R. Puca, V. Cardinale [et al.] // Stem. Cells. - 2016. - Vol. 34, No. 5. - P. 1332-1342.

7. Inflammation and hyperglycemia mediate Deaf1 splicing in the pancreatic lymph nodes via distinct pathways during type 1 diabetes / L. Yip, R. Fuhlbrigge, C. Taylor [et al.] // Diabetes. - 2015. - Vol. 64, No. 2. - P. 604-617.

8. Shevach E., Thornton A. tTregs, pTregs, and iTregs: similarities and differences / E. Shevach, A. Thornton // Immunol. Rev. - 2014. - Vol. 259, No. 1. - P. 88-102.

9. Interleukin-10 deficiency impairs regulatory $T$ cell-derived neuropilin-1 functions and promotes Th1 and Th17 immunity / S. Wang, X. Gao, G. Shen [et al.] // Sci. Rep. 2016. - Vol. 6. - P. 242-249.

10. Hammerschmidt S. Stromal mesenteric lymph node cells are essential for the generation of gut-homing $T$ cells in vivo / S. Hammerschmidt // J. Exp. Med. 2008. - Vol. 205. - P. 2483-2490.

11. Immune tolerance. Regulatory $\mathrm{T}$ cells generated early in life play a distinct role in maintaining self-tolerance / S. Yang, N. Fujikado, D. Kolodin [et al.] // Science. - 2015. - Vol. 348. - P. 589-594.

\section{REFERENCES}

1. Eades CE, Cameron DM, Evans JM. Prevalence of gestational diabetes mellitus in Europe: A meta-analysis. Diabetes Res Clin Pract. 2017;129: 173-81.

2. Ziegler SM, Feldmann $\mathrm{CN}$, Hagen $\mathrm{SH}$, Richert L, Barkhausen T, Goletzke J, Jazbutyte V, Martrus G, Salz- них Т-клітин у БЛВ. Отже, пренатальна гіперглікемія призводить до посилення прозапальної сигналізації та активації компонентів уродженої імунної системи більш виразно на 1 місяць життя.
12. Contribution of mesenteric lymph nodes and GALT to the intestinal Foxp3+Regulatory T-cell compartment / D. Geem, V. Ngo, A. Harusato // Cell Mol. Gastroenterol. Hepatol. - 2016. - Vol. 2 (3). - P. 274-280.

13. Колесник Ю. М. Диссрункция $\beta$-клеток панкреатических островков у мужского потомства самок крыс с экспериментальным гестационным диабетом / Ю. М. Колесник // Запорож. мед. журн. - 2007. - № 2. C. $5-10$

14. Stagg A. J. Intestinal dendritic cells in health and gut inflammation / A. J. Stagg // Front. Immunol. - 2018. Vol. 6. - P. 2883

15. Sricharunrat T. Oral tolerance: Recent advances on mechanisms and potential applications / T. Sricharunrat, P. Pumirat, P. Leaungwutiwong // Asian Pac. J. Allergy Immunol. - 2018. - Vol. 36 (4). - P. 207-216.

16. Spiegel $S$. The outs and the ins of sphinp gosine-1-phosphate in immunity / S. Spiegel, S. Milstien // Nat. Rev. Immunol. - 2011. - Vol. 11 (6). - P. 403-415.

17. Rivera J. The alliance of sphingosine-1-phosR phate and its receptors in immunity / J. Rivera, R. L. Proia, A. Olivera // Nat. Rev. Immunol. - 2008. - Vol. 8 (10). P. 753-763.

18. Griffith J. W. Chemokines and chemokine receptors: positioning cells for host defense and immunity / J. W. Griffith, C. L. Sokol, A. D. Luster // Annu. Rev. Immunol. - 2014. - Vol. 32. - P. 659-702.

19. Moschovakis G. L. Multifaceted activities of CCR7 regulate T-cell homeostasis in health and disease / G. L. Moschovakis, R. Förster // Eur. J. Immunol. - 2012. Vol. 42 (8). - P. 1949-1955.

20. A myriad of functions and complex regulation of the CCR7/CCL19/CCL21 chemokine axis in the adaptive immune system / I. Comerford, Y. Harata-Lee, M. D. Bunting [et al.] // Cytokine Growth Factor Rev. - 2013. - Vol. 24 (3). - P. 269-283.

21. Distinctive role of CCR7 in migration and functional activity of naive- and effector/memory-like Treg subsets / A. Menning, U. E. Hopken, K. Siegmund [et al.] // European Journal of Immunology. - 2007. -Vol. 37. - P. 1575-1583.

22. Localization of dendritic cells in the gut epithelium requires MAdCAM-1 / T. Clahsen, O. Pabst, K.Tenbrock [et al.] // Clin. Immunol. 2015. - Vol. 156, No. 1 - P. 74-84.

23. Xu B. Alpha4beta7 integrin/MAdCAM-1 adhesion pathway is crucial for $B$ cell migration into pancreatic lymph nodes in nonobese diabetic mice / B. Xu, R. E. Cook, S. A. Michie // J. Autoimmun. - 2010. - Vol. 35 (2). - P. 124-129.

berger W, Renné T, Hecher K, DiemertA, Arck PC, Altfeld M. Innate immune responses to toll-like receptor stimulai tion are altered during the course of pregnancy. J Reprod Immunol. 2018;128: 30-7.

3. Prozorova TM, Kamyshna VA, Kamyshny AM. Effect 
of experimental gestational diabetes and administration of glibenclamide on mRNA level of NLRP3-inflammasome and distribution of NLRP3 ${ }^{+}$-cells in mesenteric lymph nodes in offspring. Pathologia. 2017;14(2): 149-55.

4.DegenAS., KovalGD., SukhomlinovalE., MorozovaOV, Kamyshnyi AM. Analysis of cytoarchitectonics of TLR2+ and TLR4+ lymphocytes and transcriptional activity of the genes Gp2, Spi-B, Nf-kB1, c-REL, TNFa and TNFr IN GALT of rats in experimental diabetes mellitus and after pentoxifylline administration. Medical Immunology (Russia). 2019;21(5): 821-34.

5. Metzger T, Anderson M. Control of central and peripheral tolerance by Aire. Immunol Rev. 2011;241(1): 89103.

6. Carpino G, Puca R, Cardinale V, Renzi A, Scafetta G, Nevi L, Rossi M, Berloco PB, Ginanni Corradini S, Reid LM, Maroder M, Gaudio E, Alvaro D. Peribiliary glands as a niche of extrapancreatic precursorsyielding insulin-producing cells in experimental and human diabetes. Stem. Cells. 2016;34(5): 1332-42.

7. Yip L, Fuhlbrigge R, Taylor C, Creusot RJ, Nishikawa-Matsumura T, Whiting CC, Schartner JM, Akter R, von Herrath M, Fathman CG. Inflammation and hyperglyce $€$ mia mediate Deaf1 splicing in the pancreatic lymph nodes via distinct pathways during type 1 diabetes. Diabetes. 2015;64(2): 604-17.

8. Shevach E, Thornton A. tTregs, pTregs, and iTregs: similarities and differences. Immunol Rev. 2014;259(1): 88102.

9. Wang S, Gao X, Shen G, Wang W, Li J, Zhao J, WeiYQ, Edwards CK. Interleukin-10 deficiency impairs regulatory $T$ cell-derived neuropilin-1 functions and promotes Th1 and Th17 immunity. Sci Rep. 2016;6: 24249.

10. Hammerschmidt S. Stromal mesenteric lymph node cells are essential for the generation of gut-homing T cells in vivo. J. Exp. Med. 2008;205: 2483-90.

11. Yang S, Fujikado N, Kolodin D, Benoist C, Mathis D. Immune tolerance. Regulatory $\mathrm{T}$ cells generated early in life play a distinct role in maintaining self-tolerance. Science. 2015;348(6234): 589-94.

12. Geem D, Ngo V, HarusatoA, Chassaing B, GewirtzAT,
Newberry RD, Denning TL. Contribution of mesenteric lymph nodes and GALT to the intestinal Foxp3+ regulatory T-cell compartment. Cell Mol Gastroenterol Hepatol. 2016;2(3): 274-80.

13. Kolesnik YuM. [Pancreatic islet $\beta$-cell dysfunction in male offspring of female rats with experimental gestational diabetes]. Zaporizh med zhurn. 2007;2: 5-10. Russian.

14. Stagg AJ. Intestinal dendritic cells in health and gut inflammation. Front Immunol. 2018;6: 2883.

15. Sricharunrat $T$, Pumirat $P$, Leaungwutiwong $P$. Oral tolerance: Recent advances on mechanisms and potential applications. Asian Pac J Allergy Immunol. 2018;36(4): 20716

16. Spiegel S, Milstien S. The outs and the ins of sphingosine-1-phosphate in immunity. Nat Rev Immunol. 2011;11(6): 403-15.

17. Rivera J, Proia RL, Olivera A. The alliance of sphini gosine-1-phosphate and its receptors in immunity. Nat Rev Immunol. 2008;8(10): 753-63.

18. Griffith JW, Sokol CL, Luster AD. Chemokines and chemokine receptors: positioning cells for host defense and immunity. Annu Rev Immunol. 2014;32: 659-702.

19. Moschovakis GL, Förster R. Multifaceted activities of CCR7 regulate T-cell homeostasis in health and disease. Eur J Immunol. 2012;42(8): 1949-55.

20. Comerford I, Harata-Lee Y, Bunting MD, Gregor C, Kara EE, McColl SR. A myriad of functions and complex regulation of the CCR7/CCL19/CCL21 chemokine axis in the adaptive immune system. Cytokine Growth Factor Rev. 2013;24(3): 269-83.

21. Menning A, Hopken UE, Siegmund K, Lipp M, Hamann A, Huehn J Distinctive role of CCR7 in migration and functional activity of naive- and effector/memory-like Treg subsets. European Journal of Immunology 2007;37: 157583.

22. Clahsen T, Pabst O, Tenbrock K, Schippers A, Wagner $\mathrm{N}$. Localization of dendritic cells in the gut epithelium requires MAdCAM-1. Clin Immunol. 2015;156(1): 74-84.

23. Xu B, Cook RE, Michie SA. Alpha4beta7 integrin/ MAdCAM-1 adhesion pathway is crucial for $B$ cell migration into pancreatic lymph nodes in nonobese diabetic mice. J Autoimmun. 2010;35(2): 124-9. 